\title{
PENERAPAN UNDANG-UNDANG NO.23 TAHUN 2004 DI KABUPATEN SOLOK PERSPEKTIF HUKUM KELUARGA ISLAM
}

\author{
Afnil Farfan', Sri Yunarti ${ }^{2}$, Syaiful Marwan ${ }^{3}$ \\ ${ }^{1}$ Advokat Kota Solok, 1,2IAIN Batusangkar \\ e-mail: farfan_afnil@yahoo.co.id, Yunartisri67@gmail.com ,syaifulmarwan@iainbatusangkar.ac.id
}

\begin{abstract}
The implementation of domestic violence dispute resolution in Solok Regency is carried out in a friendly manner between the husband's family and the wife's family and the mother of both parties as mediators. If the problem cannot be resolved in a friendly manner, then the problem is resolved criminally through the Koto Baru District Court or civil settlement at the Koto Baru Religious Court. The process of resolving domestic violence by family and law at the Religious Court and Koto Baru District Court has not fully achieved the objectives of Law Number 23 of 2004 concerning PKDRT article 4 letter $d$ to maintain a harmonious and prosperous household integrity. This can be seen by the KDRT cases being settled amicably ending with legal settlement in the Religious Court and the Koto Baru District Court. The criminal settlement process at the Koto Baru District Court ended with a sentence, as well as a civil settlement at the Koto Baru Religious Court which ended in divorce. This review of Islamic Family Law on the process of resolving domestic violence in Solok Regency is in accordance with Islamic family law, as described in Surah an-Nisa verse 35 regarding sending rights in resolving husband and wife disputes. The existence of Hakam in resolving domestic disputes is not an act that violates the prevailing regulations in Indonesia, in fact, the existence of Hakam is a solution that must exist in resolving household disasters.
\end{abstract}

Kata Kunci: Penerapan, UU 23 Tahun 2004, Hukum Keluarga Islam

\section{PENDAHULUAN}

Akhir-akhir ini kekerasan dalam masyarakat tampak semakin meningkat (Moerti Hadiarti Soeroso, 2010:7). Tindakan kekerasan dalam masyarakat sebenarnya bukan suatu hal yang baru. Namun, yang menarik perhatian publik adalah kekerasan yang menimpa kaum perempuan (istri) karena sifat dan dampaknya luas bagi kehidupan kaum perempuan (La Jamaa, dan Hadidjah, 2008:85). Kekerasan jenis ini mempunyai akar yang dalam pada faktor budaya yang menempatkan perempuan pada posisi yang timpang dalam hubungannya dengan laki-laki (Moerti Hadiarti Soeroso, 2010:7). Tindak kekerasan dominan yang pernah dialami perempuan Indonesia adalah 
kekerasan di ranah domestik atau kekerasan dalam rumah tangga seperti penganiayaan, perkosaan, pelecehan atau suami berselingkuh (La Jamaa, dan Hadidjah, 2008:3).

Kekerasan dalam rumah tangga adalah masalah sosial, bukan masalah keluarga yang perlu disembunyikan. Hal ini tertuang dalam aturan yang tercantum dalam Pasal 11 UndangUndang Nomor 23 Tahun 2004 yang berbunyi:"Pemerintah bertanggung jawab dalam upaya pencegahan kekerasan dalam rumah tangga"

Keberadaan Undang-undang No. 23 tahun 2004 dilandasi oleh berbagai pertimbangan, antara lain bahwa setiap warga negara berhak mendapatkan rasa aman dan bebas dari segala bentuk kekerasan. Disahkannya Undang-undang No.23 tahun 2004 tentang Penghapusan Kekerasan dalam Rumah Tangga merupakan momen sejarah bagi bangsa Indonesia, khususnya bagi kaum perempuan dan kelompok masyarakat yang memiliki kepedulian terhadap masalah kekerasan (Moerti Hadiarti Soeroso, 2010: 6-7).

Dengan memperhatikan realita yang ada di Kabupaten Solok, bahwasanya telah terjadi kekerasan dalam rumah tangga. Dari informasi dan data yang penulis peroleh melalui sistem informasi perkara Pengadilan Agama Koto Baru, perkara perceraian yang di selesaikan dari tahun 2015 sampai dengan tahun 2018 tercatat 1.636 kasus yang terjadi di Kabupaten Solok dari 368.692 jumlah penduduk dengan 86.010 jumlah keluarga, dengan rincian sebagai berikut:

Tabel 1.1

Perkara Perceraian di Pengadilan Agama Koto Baru Tahun 2015, 2016, 2017 dan 2018

\begin{tabular}{|l|c|c|c|c|c|c|}
\hline No & Tahun & $\begin{array}{c}\text { Penelantaran } \\
\text { Rumah } \\
\text { Tangga }\end{array}$ & $\begin{array}{c}\text { Kekerasan } \\
\text { Fisik }\end{array}$ & $\begin{array}{c}\text { Sisa Tahun } \\
\text { Sebelumnya }\end{array}$ & $\begin{array}{c}\text { Jumlah } \\
\text { Perkara }\end{array}$ & $\begin{array}{c}\text { Persentase } \\
\mathbf{( \% )}\end{array}$ \\
\hline 1. & 2015 & 211 & 2 & 32 & 402 & 21 \\
\hline 2. & 2016 & 168 & 0 & 52 & 403 & 21 \\
\hline 3. & 2017 & 250 & 6 & 60 & 500 & 28 \\
\hline 4. & 2018 & 110 & 4 & 70 & 533 & 30 \\
\hline \multicolumn{2}{|c|}{ Total } & $\mathbf{7 3 9}$ & $\mathbf{1 2}$ & $\mathbf{2 1 4}$ & $\mathbf{1 8 3 8}$ & $\mathbf{1 0 0}$ \\
\hline
\end{tabular}

Sumber Data : Sistem Informasi Perkara Pengadilan Agama Koto Baru Solok

Berdasarkan data tersebut, terlihat pada tahun 2015 berjumlah 402 tercatat perkara perceraian yang perkara, tahun 2016 berjumlah 403 diselesaikan di Pengadilan Agama perkara, tahun 2017 berjumlah 500 Koto Baru dari tahun ke tahun selalu perkara dan 2018 berjumlah 533 mengalami peningkatan, hal ini perkara. Apabila dibandingkan 
dengan data perceraian yang di Pengadilan Agama Koto Baru, pada subtsansinya faktor penyebabnya adalah kekerasan dalam rumah tangga yang disebutkan dalam UU No. 23 tahun 2004 berupa kekerasan secara fisik dan penelantaran rumah tangga. Sedangkan perceraian yang dalil gugatannya dengan alasan kekerasan dalam rumah tangga yang diselesaikan di Pengadilan Agama Koto Baru, pada saat putusan diarahkan oleh majelis hakim pada perselisihan secara terus menerus diantaranya, yaitu :

Tabel 1

Perkara Perceraian dengan alasan Kekerasan dalam Rumah Tangga di Pengadilan Agama Koto Baru Tahun 2015, 2016, 2017 dan 2018

\begin{tabular}{|c|c|c|}
\hline No & Tahun & Jumlah \\
\hline 1 & 2015 & 2 \\
\hline 2 & 2016 & 5 \\
\hline 3 & 2017 & 9 \\
\hline 4 & 2018 & 10 \\
\hline & Total & 26 \\
\hline
\end{tabular}

Sumber Data: Arsip Panitera Muda Hukum Pengadilan Agama Koto Baru

Perkara perceraian dengan alasan kekerasan dalam rumah tangga di Pengadilan Agama Koto Baru dari tahun 2015 sampai tahun 2018 mengalami peningkatan. Hal ini berkaitan dengan sesuai dengan yang terdapat dalam pasal 5 UU No. 23 Tahun 2004 tentang Penghapusan Kekerasan dalam Rumah Tangga yang menerangkan bahwa seseorang dilarang melakukan kekerasan dalam rumah tangganya, dengan cara 1) Kekerasan Fisik, 2) Kekerasan psikis, 3) Kekerasan Seksual dan 4) Penelantaran Rumah Tangga. Selain data kasus kekerasan dalam rumah tangga di Pengadilan Agama Koto Baru, penulis juga menemukan data berkaitan dengan kasus kekerasan dalam rumah tangga di Pengadilan Negeri Koto Baru, diantaranya:

Tabel 2

Perkara Kekerasan dalam Rumah Tangga di Pengadilan Negeri

Koto Baru Tahun 2015, 2016, 2017 dan 2018

\begin{tabular}{|c|c|c|}
\hline No & Tahun & Jumlah Perkara \\
\hline 1. & 2015 & 2 \\
\hline 2. & 2016 & 0 \\
\hline 3. & 2017 & 6 \\
\hline 4. & 2018 & 4 \\
\hline \multicolumn{2}{|r|}{ Total } & 12 \\
\hline
\end{tabular}

Sumber Data: Sistem Informasi Perkara Pengadilan Negeri Koto Baru Solok

Penerapan Undang-Undang No. 23 Tahun 2004 di Kabupaten Solok... ｜ 143 
Berdasarkan data di atas, kasuskasus kekerasan dalam rumah tangga perlu mendapatkan perhatian bagi setiap pihak terkait untuk menangulanginya. Hal ini manandakan bahwa peranan aparat penegak hukum atau lembaga sosial yang bergerak dalam bidang penanganan terhadap perempuan mempunyai tugas yang sangat besar dalam memberikan kesadaran terhadap perempuan dan memberikan arahan kepada masyarakat agar menghindari konflik dalam rumah tangga yang dapat mengakibatkan munculnya kekerasan dalam rumah tangga.

\section{METODE PENELITIAN}

Jenis penelitian yang dilakukan adalah penelitian lapangan (field research), karena Penulis langsung melakukan penelitian di Kabupaten Solok. Penulis menggunakan metode kualitatif untuk memberikan gambaran secara sistematis, faktual dan akurat terhadap suatu populasi dan daerah tertentu, mengenai sifatsifat, karakteristik atau faktor-faktor tertentu, berfungsi menetapkan fokus penelitian, analisis data, menafsirkan data dan membuat kesimpulan atas temuannya, dalam hal ini penelitian hukum yang mempergunakan data primer yakni perempuan sebagai korban kekerasan dalam rumah tangga di Kabupaten Solok.

\section{HASIL PENELITIAN DAN PEMBAHASAN}

\section{Penyelesaian Kekerasan Dalam Rumah Tangga Dengan Pendekatan Undang-Undang Nomor 23 Tahun 2004 Di Kabupaten Solok}

Tindakan kekerasan yang dilakukan dalam ruang lingkup rumah tangga berupa kekerasan fisik, psikis, seksual maupun penelantaran rumah tangga, seringkali dimaknai sebagai ungkapan dari perasaan marah dan permusuhan suami maupun istri. Hal tersebut berdampak terhadap hilangnya kontrol terhadap diri sendiri yang menimbulkan kekerasan dalam rumah tangga. Tindakan kekerasan dalam rumah tangga tidak hanya membahayakan diri sendiri, tapi juga akan membahayakan orang lain dan lingkungan organisasi terkecil dalam masyarakat yang terbentuk karena adanya perkawinan.

Kekerasan dalam rumah tangga sering dilakukan bersamaan dengan salah satu bentuk tindak pidana, misalnya penganiayaan, pengancaman dan seterusnya sesuai yang telah diatur dalam perundang-undangan yang berlaku. Rumah tangga diawali dengan proses perkawinan, sedangkan perkawinan itu sendiri diartikan sebagai ikatan lahir batin antara seorang pria dengan seorang wanita sebagai suami istri dengan tujuan membentuk keluarga (rumah tangga) yang bahagia dan kekal berdasarkan Ketuhanan Yang Maha Esa. Landasan inilah yang kemudian menjadi dasar 
penulis untuk melakukan penelitian di Kabupaten Solok berkaitan dengan penyelesaian tindak kekerasan dalam rumah tangga.

Berdasarkan hasil wawancara penulis dengan beberapa narasumber yang penulis temui di Kabupaten Solok yaitu diantaranya Mamak dan pihak terkait mengenai penyelesaian kekerasan dalam rumah tangga yang berlaku di Kabupaten Solok. Dari data yang penulis temukan dilapangan terdapat beberapa orang yang mengalami kekerasan dalam rumah tangga dan para mamak yang menyelesaikannya. Penulis mengambil data 3 Kecamatan dari 14 Kecamatan yang ada di kabupaten Solok berkaitan dengan kasus kekerasan dalam rumah tangga diantaranya Kecamatan Kubung, Kecamatan X Koto Singkarak dan Kecamatan Lembah Gumanti. Dari tiga Kecamatan tersebut, penulis mengambil masing-masing 1 Nagari setiap Kecamatan tersebut. Diantara data yang penulis dapatkan adalah:

Tabel 3

Penyelesaian Kasus Kekerasan dalam Rumah Tangga oleh Mamak di Nagari Saniangbaka Kecamatan X Koto Singkarak, Nagari Koto Baru Kecamatan Kubung dan Nagari Aie Dingin Kecamatan Lembah Gumanti Tahun 2018

\begin{tabular}{|l|l|c|}
\hline No & \multicolumn{1}{|c|}{ Daerah } & Jumlah Kasus \\
\hline 1. & $\begin{array}{l}\text { Nagari Saniangbaka Kecamatan X } \\
\text { Koto Singkarak }\end{array}$ & 15 \\
\hline 2. & $\begin{array}{l}\text { Nagari Koto Baru Kecamatan } \\
\text { Kubung }\end{array}$ & 20 \\
\hline 3. & $\begin{array}{l}\text { Nagari Aie Dingin Kecamatan } \\
\text { Lembah Gumanti }\end{array}$ & 27 \\
\hline \multicolumn{1}{|c|}{ Jumlah } & 62 \\
\hline
\end{tabular}

Sumber: Mamak Kecamatan X Koto Singkarak, Lembah Gumanti dan Lembah Gumanti

Dari sumber data di atas yang pasangan. Sedangkan menurut $\mathrm{KZ}$ penulis dapatkan informasi dari UI (Mamak dalam Nagari Koto Baru (Mamak dalam Nagari Saniangbaka Kecamatan Kubung) menyebutkan Kecamatan X Koto Singkarak) bahwa kasus kekerasan yang pernah di menyampaikan bahwa kasus selesaikan Mamak di Nagari Koto Baru kekerasan yang di selesaikan oleh Kecamatan Kubung pada tahun 2018 Mamak yang ada di Nagari ada 20 pasangan. Kasus kekerasan Saniangbaka Kecamatan $X$ Koto dalam rumah tangga yang diselesaian Singkarak pada tahun 2018 adalah 15 oleh Mamak di Nagari Aie Dingin 
Kecamatan Lembah Gumanti pada tahun 2018 menurut $M$ adalah 27 Pasangan.

Ketika penulis bertanya berkaitan dengan proses penyelesaiannya diantara para Mamak tersebut, mereka berpendapat sama tentang proses penyelesaiannya secara kekeluargaan saja, yakninya dengan cara menasehati kemenakan mereka terlebih dahulu, baik istri maupun suami. Setelah itu mamak istri ataupun suami bertemu dan membicarakannya. Mamak pihak istri dan suami bertemu di rumah pihak istri sekaligus membawa suami istri yang terkait kekerasan dalam rumah tangga. Para mamak berusaha untuk mendamaikannya supaya tidak berakhir dengan perceraian. Dalam penyelesaian tersebut tidak semua yang berakir dengan perdamaian, tetapi juga berakhir dengan perceraian, diantara datanya sebagai berikut:

\section{Tabel 4}

Hasil Penyelesaian Kasus Kekerasan dalam Rumah Tangga oleh Mamak di Nagari Saniangbaka Kecamatan X Koto Singkarak, Nagari Koto Baru Kecamatan Kubung dan Nagari Aie Dingin Kecamatan Lembah Gumanti Tahun 2018

\begin{tabular}{|l|l|c|c|c|}
\hline No & \multicolumn{1}{|c|}{ Daerah Damai } & Cerai & Jumlah \\
\hline 1. & $\begin{array}{l}\text { Nagari Saniangbaka Kecamatan X } \\
\text { Koto Singkarak }\end{array}$ & 10 & 5 & 15 \\
\hline 2. & $\begin{array}{l}\text { Nagari Aie Dingin Kecamatan } \\
\text { Lembah Gumanti }\end{array}$ & 10 & 10 & 20 \\
\hline 3. & Nagari Koto Baru Kecamatan Kubung & 9 & 18 & 27 \\
\hline \multicolumn{2}{|c|}{ Total } & $\mathbf{2 9}$ & $\mathbf{3 3}$ & $\mathbf{6 2}$ \\
\hline
\end{tabular}

Sumber: Mamak Nagari Saniangbaka Kecamatan X Koto Singkarak, Nagari Batang Barus Lembah Gumanti dan Nagari Koto Baru Kecamatan Kubung

Selain ada kasus kekerasan menyelesaikannya secara pidana dalam rumah tangga yang berakhir melalui Pengadilan Negeri Koto Baru, dengan damai dan cerai, ada juga yang diantaranya adalah:

\section{Tabel 5}

Hasil Penyelesaian Pidana Kasus Kekerasan dalam Rumah Tangga oleh Mamak di Nagari Saniangbaka Kecamatan X Koto Singkarak, Nagari Koto Baru Kecamatan Kubung dan Nagari Aie Dingin Kecamatan Lembah Gumanti Tahun 2018 


\begin{tabular}{|l|l|c|c|}
\hline No & \multicolumn{1}{|c|}{ Daerah } & $\begin{array}{c}\text { Kasus } \\
\text { KDRT }\end{array}$ & Pidana \\
\hline 1. & $\begin{array}{l}\text { Nagari Saniangbaka Kecamatan X Koto } \\
\text { Singkarak }\end{array}$ & 15 & 1 \\
\hline 2. & $\begin{array}{l}\text { Nagari Aie Dingin Kecamatan Lembah } \\
\text { Gumanti }\end{array}$ & 20 & 1 \\
\hline 3. & Nagari Koto Baru Kecamatan Kubung & 27 & 3 \\
\hline \multicolumn{2}{|c|}{ Jumlah } & 115 & 5 \\
\hline
\end{tabular}

Sumber: Mamak Nagari Saniangbaka Kecamatan X Koto Singkarak, Nagari Batang Barus Lembah Gumanti dan Nagari Koto Baru Kecamatan Kubung

Menurut Mamak Nagari Saniangbaka Kecamatan X Koto Singkarak, Nagari Aie Dingin Lembah Gumanti dan Nagari Koto Baru Kecamatan Kubung kasus kekerasan dalam rumah tangga yang terjadi pada tahun 2018 di daerah mereka, rata-rata berawal dari faktor ekonomi. Pada saat kebutuhan dalam rumah tangga meningkat dan istri menuntut uang belanja yang sesuai dengan kebutuhan, sedangkan suami mempunyai uang yang terbatas, sehingga kebutuhan dan kemampuan yang tidak mencukupi, maka timbullah pertengkaran bahkan ada yang sampai berujung pada kekerasan fisik.

Berdasarkan keterangan Para Mamak di atas telah berupaya untuk menyelesaikan kasus kekerasan dalam rumah tangga semaksimal mungkin untuk menjaga keutuhan dalam rumah tangga. Sesuai dengan Undangundang Nomor 23 tahun 2004 tentang penghapusan kekerasan dalam rumah tangga pada pasal 4 huruf $d$ menyebutkan bahwa keberadaan Undang-undang Nomor 23 Tahun 2004 itu bertujuan untuk menjaga keharmonisan dan keutuhan dalam rumah tangga. Akan tetapi pada kenyataannya pada tiga kecamatan tersebut hanya 14 kasus yang damai sedangkan yang cerai terdapat 101 kasus dan ada 7 prosesnya berlanjut secara pidana.

Menurut pandangan penulis bahwa keberadaan Mamak sangat penting dalam menjaga dan menyelesaikan perkara kekerasan yang terjadi dalam rumah tangga. Undang-undang Nomor 23 Tahun 2004 tentang penghapusan kekerasan dalam rumah tangga merupakan aturan yang baik dalam menjaga keutuhan dan keharmonisan dalam rumah tangga.

\section{Tinjauan Hukum Keluarga Islam Terhadap Penyelesaian Perkara Kekerasan Dalam Rumah Tangga di Kabuapaten Solok}

Permasalahan dalam kehidupan rumah tangga merupakan suatu yang lumrah bagi setiap suami istri dalam mengarungi bahtera keluarga. Sehingga dari permasalahan yang ada membuat suami ataupun istri mengeluh kepada orang lain ataupun keluarganya. Hal tersebut terjadi 
karena tidak dilaksanakannya dan diperolehnya hak serta kewajiban dalam rumah tangga. Bahkan karena tidak terlaksananya ataupun diperolehnya hak dan kewajiban oleh suami istri berujung kepada perselisihan yang terus menerus, bahkan ada yang berujung pada tindakan kekerasan dalam rumah tangga. Apabila tidak bisa diselesaikan dalam ruang lingkup keluarga, bisa ada yang diproses secara pidana di Pengadilan Negeri dan adapula yang diselesaikan perdatanya di Pengadilan Agama.

Pada kasus perceraian akibat kekerasan dalam rumah tangga di Pengadilan Agama Koto Baru, lebih diarahkan pada perselisihan secara terus-menerus yang nantinya berakibat timbulkan KDRT. Proses penyelesaian perkara kekerasan dalam rumah tangga di Pengadilan Negeri Koto Baru sesuai dengan hukum pidana, yakninya dibuktikan tentang kebenaran terjadinya peristiwa pidana yang dilakukan terdakwa. Apabila terbukti bahwa telah terjadi peristiwa pidana kekerasan dalam rumah tangga yang dilakukan oleh terdakwa, maka akan dijatuhi hukuman sebagaimana yang tercantum dalam UU PKDRT No. 23 Tahun 2004 pada Bab VIII Pasal 4450. Sedangkan penyelesaian kekerasan dalam rumah tangga di Pengadilan Agama Koto Baru adalah secara perdata. Seorang istri akan mengajukan permohonan cerai gugat ke Pengadilan Agama Koto Baru dengan alasan KDRT, lalu suami istri yang terkait akan dipanggil ke Pengadilan Agama Koto Baru dan akan di mediasi terlebih dahulu supaya bisa terjadinya perdamaian sebelum masuk ke pokok perkara. Apabila tidak ada kata sepakat untuk berdamai diantara para pihak, maka majelis hakim Pengadilan Agama Koto Baru akan melakukan pemeriksaan pokok perkara, hingga nantinya diputuskan oleh Majelis Hakim yang menyelesaikan perkara.

Penyelesaian kasus kekerasan dalam rumah tangga secara hukum di Pengadilan Negeri dan Pengadilan Agama Koto Baru merupakan pilihan terakhir, setelah penyelesaian secara kekeluargaan menuju perdamaian tidak berhasil dilakukan. Berkaitan dengan penyelesaian secara kekeluargaan yang dilakukan Kabupaten Solok dengan mengutamakan peran mamak sebagai pemimpin terhadap keluarga dan kaumnya jika dilihat dalam sisi hukum Islam sama halnya dengan penyelesaian perkara rumah tangga yang disebut dengan istilah syiqaq. Syiqaq merupakan perselisihan yang terjadi terus menerus antara suami istri yang dikhawatirkan akan menimbulkan kehancuran dalam rumah tangganya (Abd. Shomad, 2010: 319).

Penyelesaian perselisihan yang berujung tindakan KDRT dalam 
Hukum Keluarga Islam terdapat pada surat an-Nisa ayat 34 dan 35 . Tindakan yang harus dilakukan pertama pada saat terjadinya perselisihan diantara suami istri adalah dengan menyelesaikannya berdua terlebih dahulu. Apabila tidak bisa diselesaikan secara berdua oleh suami dan istri, maka bisa dilakukan dengan melibatkan pihak ketiga yang perkataannya didengar oleh kedua belah pihak untuk memberikan nasihat kepada mereka. Sebagaimana firman Allah SWT dalam surat anNisa' ayat 35:

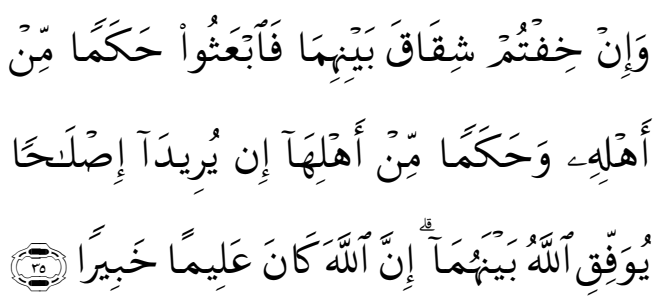

Dan jika kamu khawatirkan ada persengketaan antara keduanya, Maka kirimlah seorang Hakam dari keluarga laki-laki dan seorang Hakam dari keluarga perempuan. jika kedua orang Hakam itu bermaksud mengadakan perbaikan, niscaya Allah memberi taufik kepada suami-istri itu. Sesungguhnya Allah Maha mengetahui lagi Maha Mengenal.

Perdamaian kedua pasangan dan pembenahan keretakan dari hubungan suami istri harus diusahakan serta diperjuangkan oleh kedua orang Hakam. Apabila kedua orang Hakam tersebut telah berupaya dan berjuang untuk mendamaikan suami istri yang berselisih tersebut, akan tetapi suami istri yang didamaikan tersebut tidak dimungkinkan untuk berdamai dan diperbaiki rumah tangganya ke arah yang lebih baik, maka perpisahan (cerai) pilihan terakhir yang bisa dilakukan oleh suami istri yang berselisih.

Terobosan Islam berkaitan penyelesaian sengketa dalam rumah tangga dengan mengutus Hakam ini memiliki beberapa kelebihan, diantaranya :

1. Masalah yang menimpa ini tidak menyebar dan diketahui orang lain. Dengan kata lain, hanya pihak keluarga suami dan istri yang mengetahui perselisihan ini. Karena pada dasarnya, hanya keluarga suami dan istri yang paling perhatian akan keutuhan keluarga ini. Di sisi lain, dalam masalah semacam ini, sebaiknya orang lain tidak perlu tahu.

2. Motivasi adanya penengah dari keluarga kedua belah pihak adalah mendamaikan. Oleh karenanya, bila ada keputusan yang diambil, maka dari pihak suami dan istri akan menerimanya dengan tulus. Hal ini akan berbeda bila keputusan diambil di pengadilan, dimana biasanya satu pihak tidak puas dan memrotes keputusan itu.

3. Upaya mencari solusi ini untuk menentukan kebenaran untuk diteladani, bukan ingin memvonis suami atau istri. Karena vonis mana yang benar dan yang salah hanya akan memperparah perselisihan. 
Solusi yang ditawarkan Islam untuk mencari kesepahaman dan menyingkirkan perselisihan masa lalu (Tri Oktorinda, 2017: 63).

Indonesia mayoritas mengunakan pendapat Abu Hanafiah, Hakam itu hanya berkedudukan sebagai juru damai yang diutus oleh para keluarga kedua belah pihak, ketika tidak bisa menemukan perdamaian diantara kedua belah pihak, maka hakimlah yang berkewajiban untuk menceraikan atau tidak suami istri yang berselisih tersebut.

Bila diperhatikan surat an-Nisa ayat 35, dapat pula disimpulkan bahwa jika terjadi perselisihan antara suami istri perselisihan antara suami istri sehingga timbul permusuhan yang dikhawatirkan pisah dan hancurnya rumah tangga, maka hendaklah diadakan Hakam untuk memeriksa perkaranya dan hendaklah Hakam itu berusaha mengadakan perdamaian guna kelanggengan kehidupan rumah tangga dan hilangnya perselisihan. Dan tidak dijelaskan bahwa bila Hakam tidak dapat menemukan titik terang untuk berdamai, ceraikanlah. Ini menunjukkan bahwa Hakam dalam ayat ini hanyalah sebagai wakil yang bertujuan untuk berusaha mendamaikan kedua suami istri yang sedang berselisih yang akan mengakibatkan terjadinya perceraian.

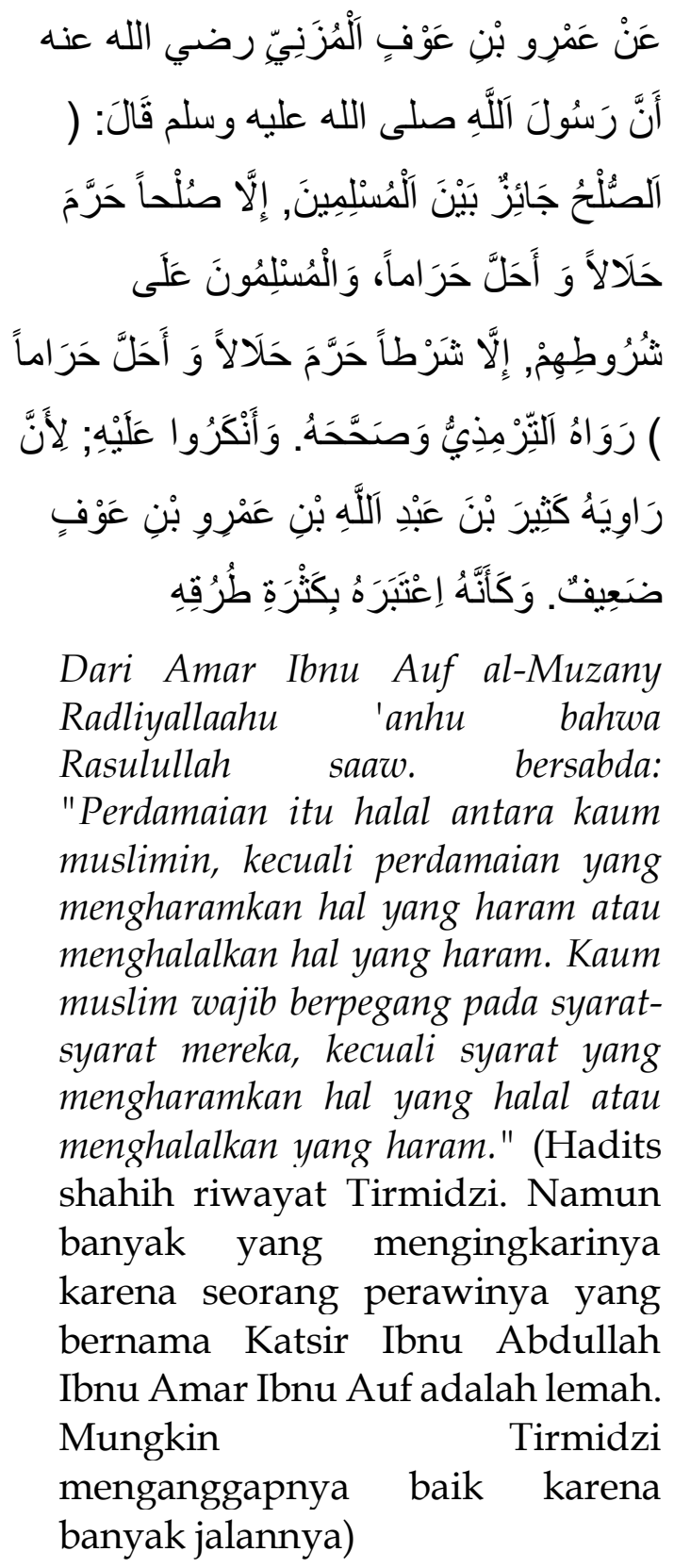

Dari Amar Ibnu Auf al-Muzany Radliyallaahu 'anhu bahwa Rasulullah saaw. bersabda: "Perdamaian itu halal antara kaum muslimin, kecuali perdamaian yang mengharamkan hal yang haram atau menghalalkan hal yang haram. Kaum muslim wajib berpegang pada syaratsyarat mereka, kecuali syarat yang mengharamkan hal yang halal atau menghalalkan yang haram." (Hadits shahih riwayat Tirmidzi. Namun banyak yang mengingkarinya karena seorang perawinya yang bernama Katsir Ibnu Abdullah Ibnu Amar Ibnu Auf adalah lemah. Mungkin

Tirmidzi menganggapnya baik karena banyak jalannya)

Pengangkatan Hakam sebagaimana yang diperintahkan dalam surat An-nisa' ayat 35, menurut Imam Syafi'i diartikan sebagai kewajiban dalam lapangan kekeluargaan saja, yaitu penyelesaian secara kekeluargaan. Namun jika secara kekeluargaan tidak dapat didamaikan lagi, barulah di datangkan hakim dari pengadilan untuk 
menyelesaikan masalah tersebut (Abd Shomad, 2010: 324).

Menurut Sayyid Sabiq, tidak disyaratkan Hakam dari pihak keluarga, artinya meskipun kedua Hakam tidak berasal dari pihak keluarga masing-masing pihak juga dibolehkan. Sedangkan perintah dalam qur'an surat an-nisa' ayat 35 tersebut hukumnya adalah sunnah bukan wajib. Dengan demikian pengangkatan Hakam dari keluarga suami istri yang berselisih tersebut bersifat sunnah atau anjuran karena keluarga adalah oerang yang dipandang lebih tahu dengan masalah tersebut (Abd Shomad, 2010: 324).

Untuk menjadi seorang Hakam menurut Sayyid Sabiq haruslah orang yang memenuhi syarat yang terdiri dari orang laki-laki yang berakal, baligh, adil, dan Islam. Sedangkan Abdul Azis Al Khuli mensyaratkan Hakam adalah seseorang yang dapat:

1) Berlaku adil diantara pihak yang berperkara

2) Dengan ikhlas berusaha mendamaikan suami istri

3) Kedua Hakam tersebut adalah orang yang disegani oleh kedua belah pihak

4) Hendaklah berpihak pada pihak yang teraniaya atau dirugikan apabila pihak yang lain tidak mau berdamai (Abd Shomad, 2010: 324).

Berdasarkan hal tersebut terlihat jelas bahwa dalam hukum keluarga Islam penyelesaian pemasalahan dalam rumah tangga dianjurkan untuk diselesaikan secara kekeluargaan menuju perdamaian dengan mendatangkan Hakam sebagai penengah dari kedua belah pihak untuk mencarikan jalan penyelesaian yang terbaik. Hakam yang menjadi penengah bertanggung jawab atas kedua suami istri yang bersengketa untuk mendamaikan keduanya sehingga hal-hal yang tidak diinginkan dapat teratasi.

Penyelesaian sengketa dalam rumah tangga berdasarkan hukum keluarga Islam sudah diterapkan dalam menyelesaikan perkara KDRT di Kabupaten Solok yang juga mengupayakan penyelesaian secara kekeluargaan dalam mencari perdamaian antara suami istri yang bersengketa. Mamak Kepala Kaum dari masing-masing pihak suami istri ditunjuk sebagai Hakam dalam menyelesaikan sengketa suami istri ini. Mamak merupakan orang yang dihormati dan ditinggikan kedudukannya dalam kaum.

Penyelesaian KDRT secara kekeluargaan dengan mengutus Hakam dalam memperjuangkan perdamaian dalam keharmonisan dan keutuhan rumah tangganya merupakan cara yang terbaik untuk menghindarkan suami istri dari penyelesaian secara pidana yang nantinya akan berdampak pada kehidupan rumah tangganya di masa yang akan datang. Ketika penyelesaian 
KDRT secara pidana juga akan merusak hubungan kekeluargaan diantara suami istri yang bersengketa.

Proses penyelesaian secara pidana yang dilakukan di Pengadilan Negeri akan berimplikasi pada penahanan terhadap terdakwa perkara kekerasan dalam rumah tangga. Ketika terdakwa di tahan, tentunya dia tidak bisa seperti biasa melaksanakan hak dan kewajiban sebagai suami istri. Terdakwa ketika ditahan tidak bisa memenuhi kewajiban nafkah terhadap istri dan anaknya. Sehingga akan menimbulkan akibat yang buruk pada kehidupan istri dan anaknya yang dalam Islam hal ini disebut dengan istilah mashlahah. Mashlahah yaitu mengambil manfaat dan menolak kemudaratan dalam rangka memelihara tujuan-tujuan syara' (Nasrun Harun, 1997: 114).

Menurut 'Izz al-Din 'Abd al-Aziz ibn 'Abd al-Salam, sebagaimana dikutip Djazuli, keseluruhan hukum Islam yang terinci dalam pelbagai bidang hukum bertujuan untuk meraih maslahat dan menolak mafsadat. Keseluruhan taklif yang tercermin dalam konsep al-ahkam alkhamsah (wajib, Sunah, mubah, makruh dan haram) kembali pada kemaslahatan hamba di dunia dan akhirat. Demikian pula penelitian yang dilakukan oleh Ibn al-Qayyim terhadap teks-teks al-Quran dan Sunah menyimpulkan bahwa syariat Islam dibangun untuk kepentingan manusia dan tujuan-tujuan kemanusiaan yang universal yakni keadilan, kerahmatan, kemaslahatan dan kebijaksanaan atau mengandung makna (hikmah) bagi kehidupan. Prinsip-prinsip ini harus menjadi dasar dan substansi dari seluruh persoalan hukum Islam. Penyimpangan terhadap prinsipprinsip ini berarti bertentangan dengan cita-cita syariat atau agama. Dengan demikian, setiap hal yang zalim dan tidak memberi rahmat bukanlah hukum Islam (Asni, 2014: 106). Menolak kemudharatan maksudnya adalah penelantaran yang dapat menimbulkan kesengsaraan ketika kewajiban nafkah terdakwa terhadap istri dan anaknya tidak dapat terpenuhi dengan baik.

Penyelesaian secara hukum hanyalah pada kasus kekerasan dalam rumah tangga yang tidak dapat diselesaikan secara kekeluargaan. Penyelesaian ini sejalan dengan prinsip Islam bahwa ketika terjadi sengketa diantara suami istri maka ditunjuk Hakam dari kedua belah pihak. Jika tidak berhasil menemukan kata sepakat dalam perdamaian terhadap suami istri yang bersengketa tersebut, maka jalan berikutnya yang dilakukan adalah dengan menyelesaikan perkara tersebut secara pidana di Pengadilan Negeri ataupun diselesaikan secara perdata di Pengadilan Agama. 


\section{PENUTUP}

\section{Kesimpulan}

Berdasarkan hasil penelitian dan pembahasan yang telah penulis lakukan di Kabupaten Solok mengenai "Penyelesaian Kekerasan Dalam Rumah Tangga dengan Pendekatan Undang-Undang Nomor 23 Tahun 2004 Di Kabupaten Solok Perspektif Hukum Keluarga Islam", maka dapat ditarik kesimpulan sebagai berikut :

1. Proses penyelesaian kekerasan dalam rumah tangga di Kabupaten Solok dilakukan secara kekeluargaan antara pihak keluarga suami dan pihak keluarga istri serta mamak kedua belah pihak sebagai penengah. Apabila masalah tersebut tidak bisa diselesaikan secara kekeluargaan, maka masalah itu diselesaikan secara pidana melalui Pengadilan Negeri Koto Baru maupun penyelesaian secara perdata di Pengadilan Agama Koto Baru.

2. Proses penyelesaian kekerasan dalam rumah tangga secara kekeluargaan maupun hukum di Pengadilan Agama dan Pengadilan Negeri Koto Baru belum sepenuhnya mencapai tujuan dari UU Nomor 23 tahun 2004 tentang PKDRT pasal 4 huruf d untuk menjaga keutuhan rumah tangga yang harmonis dan sejahtera. Hal ini terlihat dengan perkara KDRT diselesaikan secara kekeluargaan berakhir dengan Penyelesaian secara hukum di Pengadilan Agama dan Pengadilan Negeri Koto Baru. Proses penyelesaian secara pidana ke Pengadilan Negeri Koto Baru berakhir dengan hukuman, serta penyelesaian secara perdata di Pengadilan Agama Koto Baru yang berakhir dengan perceraian.

Tinjauan Hukum Keluarga Islam terhadap proses penyelesaian kekerasan dalam rumah tangga di Kabupaten Solok ini sesuai dengan hukum keluarga Islam, sebagaimana yang dijelaskan dalam surat an-Nisa ayat 35 tentang mengutus hakam dalam menyelesaikan perselisihan suami istri. Keberadaan Hakam dalam penyelesaian sengketa dalam rumah tangga bukan merupakan perbuatan yang menyalahi aturan yang berlaku di Indonesia, bahkan kehadiran Hakam justru menjadi solusi yang harus ada dalam penyelesaian prahara rumah tangga.

\section{Saran}

Penerapan UU dalam penelitian ini diharapkan dapat memberikan berbagai masukan mengenai penerapan aturan hukum dalam berbagai permasalahan dalam kehidupan rumah tangga. 


\section{KEPUSTAKAAN ACUAN}

Abd Shomad, 2010, Hukum Islam, Jakarta: Kencana

Abdul Aziz Muhammad Azzam dan Abdul Wahhab Sayyed Hawwas, 2014, Fiqh Munakahat Khitbah, Nikah dan Talak, Jakarta: Amzah (Terjemahan: Abdul Majid Khon)

Abdul Aziz, Islam dan Kekerasan Dalam Rumah Tangga, Kordinat Vol. XVI No. 1 April 2017

Abdul Hamid, 1995, Bimbingan Islam untuk Menuju Keluarga Sakinah, Bandung: al- Bayan Mizan

Abdul Manan, 2008, Penerapan Hukum Acara Perdata di Lingkungan Peradilan Agama, Jakarta: Kencana

Abdul Rahman Ghozaly, 2003, Figh Munakahat, Jakarta Timur : Prenada Media

Abu Malik Kamal bin As- Sayyid Salim, 2007, Shahih Fikih Sunnah, Jakarta: Pustaka Azzam, Cet. I

Achmad Warson Munawwir, 1997, AlMunawwir, Yogyakarta: Pustaka Progresif

Adil Samadani, 2013, Kompetensi Pengadilan Agama Terhadap Tindak Kekerasan dalam Rumah Tangga, Yogyakarta: Graha Ilmu

Ahmad al-Khumayini, t.t., al-Ahwal asSyakhshiyyah, Beirut Lubnan: Dar al-Fikr
Ahmad Azhar Basyir, 2000, Hukum Perkawinan Islam, Yogyakarta : UII Press

Ahmad Rofiq, 2013, Hukum Perdata Islam di Indonesia, Edisi Revisi, Jakarta: Raja Grafindi Persada

Ahmad Wardi Muslich, 2004, Pengantar dan Azas Hukum Pidana Islam Fiqh Jinayah, Jakarta: Sinar Grafika, Cet. 1

Ali ibn Ahmad al-Wahidi, 1992, Asbab al-Nuzul Al-Qur'an, Asam bin Abdul Muhsin (ed), Dimām: Dār al-Islah, cet. Kedua

Ali Yusuf As Subki, 2010, Figh Keluarga Pedoman Berkeluarga dalam Islam, Jakarta: Amza

Al-Qurtubi, t.th, Jami' al-Ahkam alQur'an, Mesir: Dar al-Kitab al'Arabi

Asni, Pertimbangan Maslahat dalam Putusan Perceraian Akibat Kekerasan Dalam Rumah Tangga di Pengadilan Agama, Ahkam: Vol. XIV, No. 1, Januari 2014

La Jamaa, dan Hadidjah, 2008, Hukum Islam dan Undang-undang Anti Kekerasan dalam Rumah Tangga, Surabaya: PT. Bina Ilmu

Moerti Hadiati Soeroso, 2010, Kekerasan Dalam Rumah Tangga (Dalam Perspektif YuridisVictimlogis), Jakarta: Sinar Grafika

Nasrun Harun, 1997, Ushul Figh I, Jakarta : Logos Wacana Ilmu 